\title{
Lifestyle change in Kerala, India: needs assessment and planning for a community-based diabetes prevention trial
}

\author{
Meena Daivadanam ${ }^{1,2^{*}}$, Pilvikki Absetz ${ }^{3}$, Thirunavukkarasu Sathish ${ }^{4}, \mathrm{~K} R$ Thankappan ${ }^{1}$, Edwin B Fisher ${ }^{5}$, \\ Neena Elezebeth Philip ${ }^{1}$, Elezebeth Mathews ${ }^{1}$ and Brian Oldenburg ${ }^{4}$
}

\begin{abstract}
Background: Type 2 Diabetes Mellitus (T2DM) has become a major public health challenge in India. Factors relevant to the development and implementation of diabetes prevention programmes in resource-constrained countries, such as India, have been under-studied. The purpose of this study is to describe the findings from research aimed at informing the development and evaluation of a Diabetes Prevention Programme in Kerala, India (K-DPP).
\end{abstract}

Methods: Data were collected from three main sources: (1) a systematic review of key research literature; (2) a review of relevant policy documents; and (3) focus groups conducted among individuals with a high risk of progressing to diabetes. The key findings were then triangulated and synthesised.

Results: Prevalence of risk factors for diabetes is very high and increasing in Kerala. This situation is largely attributable to rapid changes in the lifestyle of people living in this state of India. The findings from the systematic review and focus groups identified many environmental and personal determinants of these unhealthy lifestyle changes, including: less than ideal accessibility to and availability of health services; cultural values and norms; optimistic bias and other misconceptions related to risk; and low expectations regarding one's ability to make lifestyle changes in order to influence health and disease outcomes. On the other hand, there are existing intervention trials conducted in India which suggests that risk reduction is possible. These programmes utilize multi-level strategies including mass media, as well as strategies to enhance community and individual empowerment. India's national programme for the prevention and control of major non-communicable diseases (NCD) also provide a supportive environment for further community-based efforts to prevent diabetes.

Conclusion: These findings provide strong support for undertaking more research into the conduct of community-based diabetes prevention in the rural areas of Kerala. We aim to develop, implement and evaluate a group-based peer support programme that will address cultural and family determinants of lifestyle risks, including family decision-making regarding adoption of healthy dietary and physical activity patterns. Furthermore, we believe that this approach will be feasible, acceptable and effective in these communities; with the potential for scale-up in other parts of India.

Keywords: Diabetes mellitus, Real world intervention, Diabetes prevention, Pre-diabetes

\footnotetext{
* Correspondence: meenadaivadanam@live.in

${ }^{1}$ Achutha Menon Centre for Health Science Studies, Sree Chitra Tirunal

Institute for Medical Sciences and Technology, Trivandrum, Kerala, India

${ }^{2}$ Division of Global Health (IHCAR), Department of Public Health Sciences,

Karolinska Institutet, Nobels vag 9, Stockholm 171 77, Sweden

Full list of author information is available at the end of the article
} 


\section{Background}

\section{Type 2 Diabetes Mellitus is a major public health issue in India}

Next only to China, India has the second largest number (>61 million) of individuals with Type 2 Diabetes Mellitus (T2DM) in the world and this is expected to nearly double by 2030 [1]. The national T2DM prevalence in 2011 was already 8.3 percent [1]. Furthermore, a large proportion of individuals are at "high risk" of progression to diabetes [1] which occurs more quickly than in most developed countries [2]. These observations, together with the high rates of complications and mortality [3] associated with T2DM, demonstrate that diabetes prevention should be an urgent priority for the government and other organizations in India.

\section{Evidence supports lifestyle interventions for diabetes prevention}

A number of efficacy trials from China [4], Finland [5], U.S.A. [6], India [7] and Japan [8] provide strong empirical support for lifestyle change programmes in preventing T2DM among individuals with impaired glucose tolerance (IGT). Reduction in T2DM incidence ranged between $42-58 \%$ in these various trials [5,7,9-12], with generally good maintenance for up to 20 years [4]. Moreover, behavioural interventions have been shown to be more costeffective than drug treatment $[13,14]$, particularly when delivered via group-based intervention programmes [15]. A series of ensuing implementation trials conducted in different countries in recent years [7,16-18] have now also demonstrated that the findings from efficacy trials can be replicated in 'real world' community settings with more feasible, acceptable and cost-effective delivery systems $[19,20]$ and with similar outcomes [5,16,21-24].

\section{Transferability and uptake in resource poor settings requires critical evaluation}

The majority of these efficacy and implementation trials except the Da-Qing study in China and the Indian Diabetes Prevention Programme (IDPP) - were developed and delivered in developed countries that are very different from rapidly developing countries in terms of their health systems, culture, traditions and lifestyle behaviours related to nutrition and diet. Most of these programmes were also undertaken in countries, where there was quite a strong enabling environment of policy and other supports for the prevention and control of chronic non-communicable diseases (NCDs) aimed at increasing population awareness of lifestyle-related risk $[25,26]$. These programmes have typically focused on weight loss, greater intake of fiber, reduced total and saturated fat and increase in daily physical activity [5]. Most of these programmes have also used behaviour change approaches and techniques that have emphasised outcome expectations, self-efficacy, setting of individual goals and creation of specific action plans in order to achieve lifestyle change in key behaviours. However, the socio-behavioural approaches and models on which these strategies are based have also been largely derived from health behaviour theories and models that have been primarily developed in Europe and the United States $[27,28]$. Currently, there is little research concerning the factors that influence the feasibility and adaptation of T2DM prevention programmes to more resource constrained countries, cultures and settings [29].

The state of Kerala in India has high literacy (90.9\%) and is the most advanced in terms of demographic and epidemiological transition, with the largest proportion of elderly and those suffering from NCDs, including diabetes $[30,31]$. However, as is the case in most of India, the majority $(76 \%)$ of Kerala's 33 million inhabitants reside in non-urban areas [31]. These factors make rural Kerala an ideal setting in which to trial and develop new approaches to T2DM prevention as commentators have suggested that the rest of India is likely to become like Kerala in the future [30]. In other words, interventions developed and evaluated in Kerala have the potential to be adopted elsewhere in India in the future.

This paper describes the findings from a needs assessment for a diabetes prevention programme in Kerala by triangulating and synthesizing the evidence from three different sources:

1) A review of empirical studies relevant to understanding lifestyle risk factors, their determinants and lifestyle interventions for diabetes prevention in India and more specifically, Kerala.

2) A review of policy and other documents relevant to diabetes prevention in India and Kerala.

3) A focus group study concerning lay perceptions of T2DM and its prevention in Kerala.

Our aim is to show how these findings would inform the design and delivery of the intervention programme for the Kerala Diabetes Prevention Programme (K-DPP).

\section{Methods}

The methodology and conduct of data collection and analysis for each of the three data sources are described below. The needs assessment study was carried out between February 2010 and April 2012, when the final update for the literature searches was conducted.

\section{Review of empirical studies}

Research literature search was confined to studies related to diet, physical activity and tobacco use in relation to noncommunicable diseases, their risk factors and determinants in India and Kerala in particular, identified through the PubMed database. Four searches were conducted in the 
Pubmed database using MeSH terms related to diet, physical activity, tobacco use and health promotion interventions in India. Tobacco use was included as it has recently been recognised as a risk factor of T2DM [32]. Complete search strategy and search results are presented in Additional file 1. All available abstracts were reviewed and relevant articles were obtained through the Internet or directly from the authors. Publications that were unavailable are not included in the review. Our focus was on identifying relevant epidemiological studies concerning the major social and behavioural risk factors and non-pharmacological intervention studies. For the intervention studies, we applied the following inclusion criteria: dietary, physical activity, tobacco-related or lifestyle modification interventions conducted in India among adult population $(>/=19$ years) looking at individual risk factor modification alone or in combination with life-style modification for diabetes, cardiovascular diseases or NCDs and published in the last 10 years. Nine intervention studies were identified and two could not be accessed even after writing to the authors. The remaining seven studies are listed in Table 1.

\section{Review of policy and other relevant documents}

Policy documents related to national and state capacity, legislation, programmes and guidelines for NCD prevention and control, diet, physical activity, tobacco and alcohol were searched using Google search engine from the official websites of related government departments in India (Ministry of Health and Family Welfare, Government of India; Government of Kerala; and National Rural Health Mission). Initially the documents were accessed and reviewed by two of the authors (MD, PA). The list was then counter-checked for completion by members of the research team in Kerala (KRT, ST, NEP, EM). The reality of the reports in terms of actual work going on in Kerala was corroborated through the State Nodal Officer (NCD) under National Rural Health Mission (NRHM) in Kerala and the Additional Director of Health Services (Public Health), Directorate of Health Services, Government of Kerala.

\section{Conduct of focus groups}

A sub-group of individuals with pre-diabetes (fasting blood glucose $110-125 \mathrm{mg} / \mathrm{dl}$ ), who had participated in an earlier community-based survey in Trivandrum District in 2007-2008 and residing in rural areas [33], were invited by telephone to participate in a focus group discussion (FGD) related to their views on T2DM and its prevention. Of 84 individuals, 37 had incorrect phone numbers, 13 did not respond and 16 refused to participate, resulting in 18 participants in three FGDs. The first two FGDs were conducted separately among men $(\mathrm{n}=6$; age: median: 54 yrs; range: $35-64$ yrs) and women $(n=6$; age: median: 48 yrs; range: $33-63$ yrs) with focus on the community's understanding of diabetes, sources and use of health information, and interest in and feasibility and acceptability of interventions. The third FGD ( $\mathrm{n}=6$; age: median: 59 yrs; range: 40-64 yrs.) had an equal number of male and female participants and built on the findings from the previous FGDs to understand more about issues related to programme implementation and delivery.

An interview guide (Additional file 2) was prepared to help the moderator (MD) cover four main areas during the focus group discussion: 1) understanding of diabetes and level of interest to know more; 2) health information sources and access to them; 3 ) motivation to participate in a community-based diabetes prevention programme; and 4) how such a programme should be delivered and by whom? The FGDs were conducted in a health center run by a local non-governmental organization (NGO), Health Action by People (HAP) who conducted the original research [33]. Ethical clearance was obtained from the institutional review boards of Monash University, Melbourne, Australia and Sree Chitra Tirunal Institute for Medical Sciences and Technology, Trivandrum, Kerala for the K-DPP study and its development. Moreover, telephone invitations to participate in the FGDS were issued only after individuals with pre-diabetes were identified and approached by members of the NGO and informed about the present study. In addition, all participants gave informed consent before the FGDs were conducted. The FGDs were recorded on tape and transcribed verbatim before translation into English. Manifest content analysis [34] was performed using a combination of manual and software methods (Weft QDA, version 1.0.1.). Meaning units were initially identified from the text, condensed and coded; then interlinked to identify the main themes.

\section{Triangulation and synthesis of findings from different sources}

Triangulation was used to integrate multiple data sources to improve the understanding of the diabetes problem in Kerala; to strengthen our interpretations; and to guide our decision-making to address the problem with an intervention based on available evidence [35]. In our synthesis, research literature corresponds to the currently available evidence base; policy documents reflect the policies and the programmes that underpin the public health practice related to NCDs in India; and the FGDs help inform our understanding of what people from the community really think about diabetes prevention, and how effective and realistic intervention strategies can be developed and tested.

\section{Results}

Review of empirical studies

Risk factors

Indian states show a wide variation in NCD prevalence, with Kerala ranking at the top. In comparison to the $8 \%$ 
Table 1 Details of completed non-communicable disease intervention studies in the Indian context

\begin{tabular}{|c|c|c|c|c|c|}
\hline \multirow{2}{*}{$\begin{array}{l}\text { Study (Author) } \\
\text { Target risk factor }\end{array}$} & \multirow[t]{2}{*}{ Target population } & \multirow[t]{2}{*}{ Study design } & \multicolumn{2}{|c|}{ Intervention } & \multirow[t]{2}{*}{ Study outcomes } \\
\hline & & & Components & Response & \\
\hline \multirow{4}{*}{$\begin{array}{l}\text { 1. Indian Diabetes } \\
\text { Prevention } \\
\text { Programme (IDPP) } \\
\text { 1\&2 (Ramachandran } \\
\text { A et al. 2010): Risk for } \\
\text { and incidence of } \\
\text { T2DM }\end{array}$} & \multirow{4}{*}{$\begin{array}{l}\text { - Follow-up of } 845 \text { out } \\
\text { of } 869 \text { IGT subjects } \\
\text { from IDPP 1and } 2 \\
\text { studies,recruited from } \\
\text { clinic setting followed } \\
\text { up for } 3 \text { years } \\
\text { - } 2 \text { groups of } \\
\text { participants: Group } 1 \\
\text { ( } n=667) \text { : Baseline } \\
\text { isolated IGT; Group } 2 \\
\text { ( } n=178) \text { : IGT+IFG }\end{array}$} & \multirow{4}{*}{$\begin{array}{l}\text { - } 3 \text { yr RCT } \\
\text { - IDPP 1: } 4 \text { groups } \\
\text { 1) Control with } \\
\text { standard advice: } \\
\text { 2) LSM } \\
\text { 3) Metformin } \\
\text { (500 mg/day) } \\
\text { 4) LSM + Metformin } \\
\text { - IDPP 2: } 2 \text { groups } \\
\text { 1) LSM + placebo } \\
\text { 2) LSM + Pioglitazone } \\
\text { (30 mg/day) }\end{array}$} & Individual: & \multirow{4}{*}{$\begin{array}{l}\text { - IDPP 1: } 502 \text { out of } 531 \\
\text { (94.5\%) participants } \\
\text { found to have IGT after } \\
\text { standard Oral Glucose } \\
\text { Tolerance Test (OGTT) } \\
\text { - IDPP 2: } 367 \text { out of } 407 \\
\text { (90.2\%) participants } \\
\text { found to have IGT after } \\
\text { standard OGTT }\end{array}$} & \multirow{4}{*}{$\begin{array}{l}\text { - IDPP-1: Decrease in } \\
\text { relative risk 29\% (LSM), } \\
\text { 26\% (Metformin) \& 28\% } \\
\text { (LSM+Metformin) } \\
\text { - IDPP-2: Cumulative } \\
\text { incidences at } 36 \\
\text { months: 30\% (LSM } \\
\text { +Pioglitazone) \& 32\% } \\
\text { (LSM+placebo) } \\
\text { - No additional benefit } \\
\text { with drugs }\end{array}$} \\
\hline & & & $\begin{array}{l}\text { - Personal sessions at } \\
6 \text {-month intervals }\end{array}$ & & \\
\hline & & & $\begin{array}{l}\text { - } 0.15-0.75 \text { h/year by } \\
\text { dietician \& social } \\
\text { worker \& monthly } \\
\text { telephone contacts }\end{array}$ & & \\
\hline & & & $\begin{array}{l}\text { - LSM: diet \& physical } \\
\text { activity modification }\end{array}$ & & \\
\hline \multirow{7}{*}{$\begin{array}{l}\text { 2. Diabetes } \\
\text { Prevention \& } \\
\text { Management (DPM) } \\
\text { programme } \\
\text { (Balagopal P et al. } \\
\text { 2008): Proportion with } \\
\text { high fasting blood } \\
\text { glucose levels }\end{array}$} & \multirow{7}{*}{$\begin{array}{l}850 \text { village inhabitants, } \\
\text { comprising adults and } \\
\text { youth aged 10-92 } \\
\text { years (included healthy, } \\
\text { impaired fasting } \\
\text { glucose and T2DM } \\
\text { individuals) }\end{array}$} & \multirow{7}{*}{$\begin{array}{l}\text { 7-month community- } \\
\text { based non- } \\
\text { pharmacological } \\
\text { lifestyle intervention }\end{array}$} & Individual: & \multirow{7}{*}{$\begin{array}{l}\text { - Total eligible } \\
\text { residents: } 950 \\
\text { - Baseline survey: } 850 \\
\text { - Post-intervention } \\
\text { survey: } 703 \text { (Attrition } \\
\text { rate due to migrations } \\
\text { \& refusals: } 17 \% \text { ) } \\
\text { - Response rate at } \\
\text { baseline: } 89.5 \%\end{array}$} & \multirow{7}{*}{$\begin{array}{l}\text { FBG levels decreased } \\
\text { by 3\% (healthy adults), } \\
11 \% \text { (adults with IFG), } \\
17 \% \text { (youth with IFG) \& } \\
25 \% \text { (adults with T2DM) }\end{array}$} \\
\hline & & & $\begin{array}{l}\text { - } 10 \text { face-to-face } \\
\text { interviews }\end{array}$ & & \\
\hline & & & Group: & & \\
\hline & & & $\begin{array}{l}\text { - Culturally sensitive } \\
\text { sessions on physical } \\
\text { activity \& diet }\end{array}$ & & \\
\hline & & & Community: & & \\
\hline & & & $\begin{array}{l}\text { - Participatory analysis } \\
\text { of village }\end{array}$ & & \\
\hline & & & $\begin{array}{l}\text { - Involvement of village } \\
\text { leaders, peer educators } \\
\text { \& residents }\end{array}$ & & \\
\hline \multirow{4}{*}{$\begin{array}{l}\text { 3. Chennai Urban } \\
\text { Population Study-17 } \\
\text { (Mohan V et al., } \\
\text { 2006): Physical } \\
\text { inactivity }\end{array}$} & \multirow{4}{*}{$\begin{array}{l}\text { All individuals above } \\
\text { age of } 20 \text { living in two } \\
\text { residential colonies of } \\
\text { urban Chennai }\end{array}$} & \multirow{4}{*}{$\begin{array}{l}\text { Community-based } \\
\text { intervention for } \\
\text { increasing physical } \\
\text { activity. Baseline cross- } \\
\text { sectional survey and a } \\
\text { 7-yr follow-up cross- } \\
\text { sectional survey. }\end{array}$} & Individual: & \multirow{4}{*}{$\begin{array}{l}\text { - Baseline cross- } \\
\text { sectional survey (1996): } \\
479 \text { out of } 524 \text { eligible } \\
\text { participants }(91.4 \%) \\
\text { - } 7 \text {-yr follow-up cross- } \\
\text { sectional survey (2004): } \\
705 \text { out of } 712 \text { eligible } \\
\text { participants (99\%) }\end{array}$} & \multirow{4}{*}{$\begin{array}{l}\text { - Proportion of light- } \\
\text { grade activity reduced } \\
\text { in both men (55\% to } \\
36 \% \text { ) and women ( } 74 \% \\
\text { to } 57 \% \text { ) } \\
\text { - Proportion of } \\
\text { residents exercising } \\
\text { increased from } 14 \% \text { to } \\
59 \% \\
\text { - Community's } \\
\text { response: residents } \\
\text { mobilised resources } \\
\text { and constructed a park. }\end{array}$} \\
\hline & & & $\begin{array}{l}\text { - Culturally tailored } \\
\text { education campaign \& } \\
\text { materials, social worker } \\
\text { visits- Diabetes and } \\
\text { high risk intervention: } \\
\text { information on diabetic } \\
\text { status \& individual } \\
\text { counseling }\end{array}$ & & \\
\hline & & & Population: & & \\
\hline & & & $\begin{array}{l}\text { - Awareness } \\
\text { programme using } \\
\text { public lectures, video } \\
\text { clippings \& short skits }\end{array}$ & & \\
\hline $\begin{array}{l}\text { 4. Community-based } \\
\text { intervention in } \\
\text { Ballabgarh, India } \\
\text { (Krishnan A et al. } \\
\text { 2010): Non- } \\
\text { communicable disease } \\
\text { risk factors }\end{array}$ & $\begin{array}{l}\text { Residents in urban } \\
\text { areas of Ballabgarh } \\
\text { block, Faridabad } \\
\text { district, Haryana (near } \\
\text { New Delhi) }\end{array}$ & $\begin{array}{l}\text { - Community-based } \\
\text { demonstration project } \\
\text { using the Health } \\
\text { Settings approach. } \\
\text { - Cross-sectional } \\
\text { surveys at pre- } \\
\text { intervention and 3- } \\
\text { year follow-up: pre- } \\
\text { intervention survey in } \\
\text { 2003-04 and post- } \\
\text { intervention survey in } \\
\text { 2006-07 }\end{array}$ & $\begin{array}{l}\text { Individual: } \\
\text { - Advocacy and } \\
\text { medication } \\
\text { - Individual } \\
\text { empowerment } \\
\text { Community: } \\
\text { - Social enhancement } \\
\text { and community } \\
\text { empowerment } \\
\text { - Reorientation of } \\
\text { health services }\end{array}$ & Not mentioned & $\begin{array}{l}\text { - Programme reach } \\
\text { (proportion of } \\
\text { community who came } \\
\text { in contact with the } \\
\text { programme): } 25 \% \\
\text { - Change from baseline } \\
\text { proportion: consuming } \\
<5 \text { servings of fruits } \\
\text { and vegetables } \\
\text { decreased by } 3 \% \\
\text { (men), } 5 \% \text { (women); } \\
\text { Elevated BP decreased } \\
9 \% \text { (men), } 2 \% \text { (women) }\end{array}$ \\
\hline
\end{tabular}




\section{Table 1 Details of completed non-communicable disease intervention studies in the Indian context (Continued)}

\begin{tabular}{|c|c|c|c|c|c|}
\hline $\begin{array}{l}\text { 5. Work site } \\
\text { intervention } \\
\text { programme on } \\
\text { cardiovascular risk } \\
\text { factors (Prabhakaran } \\
\text { et al. 2009): } \\
\text { Cardiovascular risk } \\
\text { factors }\end{array}$ & $\begin{array}{l}\text { Employees and their } \\
\text { family members (age } \\
\text { 10-69 years) from } 10 \\
\text { centres (Bangalore, } \\
\text { Coimbatore, Delhi, } \\
\text { Dibrugarh, Hyderabad, } \\
\text { Lucknow, Ludhiana, } \\
\text { Nagpur, Pune and } \\
\text { Trivandrum) }\end{array}$ & $\begin{array}{l}\text { Work site } \\
\text { demonstration project: } \\
\text { - Intervention sites: } \\
\text { Baseline cross- } \\
\text { sectional survey, } \\
\text { 4-year health } \\
\text { intervention } \\
\text { programme and a } \\
\text { repeat cross-sectional } \\
\text { survey. } \\
\text { - Control sites: } \\
\text { Baseline cross- } \\
\text { sectional survey, } \\
\text { 4-year minimal } \\
\text { interventions and a } \\
\text { repeat cross-sectional } \\
\text { survey. }\end{array}$ & $\begin{array}{l}\text { Individual: } \\
\text { - One-on-one } \\
\text { interactions between } \\
\text { the trained health } \\
\text { project personnel and } \\
\text { the participants } \\
\text { Group: } \\
\text { - Dynamic group } \\
\text { interactions and } \\
\text { healthy meals } \\
\text { Population or } \\
\text { community: } \\
\text { - Use of posters, } \\
\text { banners at strategic } \\
\text { locations in the } \\
\text { industry } \\
\text { - Handouts, booklets } \\
\text { and video films shown } \\
\text { on the internal cable } \\
\text { network }\end{array}$ & $\begin{array}{l}\text { - Baseline cross- } \\
\text { sectional survey: } \\
\text { Intervention sites: } \\
82.4 \% \text { and control site: } \\
90.0 \% \\
\text { - Repeat cross-sectional } \\
\text { survey: Intervention } \\
\text { sites: } 98.3 \% \text { and control } \\
\text { site: } 90.7 \%\end{array}$ & $\begin{array}{l}\text { Change in proportion } \\
\text { of risk factors in } \\
\text { intervention vs. control } \\
\text { sites: tobacco use: } 39 \% \\
\text { to } 29 \% \text { vs. } 17 \% \text { to } 20 \% \text {, } \\
\text { extra salt use: } 28 \% \text { to } \\
13 \% \text { vs. } 22 \% \text { to } 25 \% \text {, } \\
\text { median physical activity } \\
\text { score: } 6 \text { to } 11 \text { vs. } 8 \text { to } 6 \text {, } \\
\text { fruit consumption: } 38 \% \\
\text { to } 45 \% \text { vs. } 36 \% \text { to } 38 \%\end{array}$ \\
\hline $\begin{array}{l}\text { 6. Community-based } \\
\text { intervention for } \\
\text { tobacco cessation in } \\
\text { rural Tamil Nadu, } \\
\text { India: A cluster } \\
\text { randomised trial } \\
\text { (Kumar MS et al. } \\
\text { 2012): Tobacco use } \\
\text { (smoking and } \\
\text { smokeless tobacco) }\end{array}$ & $\begin{array}{l}\text { Men aged } 20-40 \text { years } \\
\text { using any form of } \\
\text { tobacco who were } \\
\text { residing in } \\
\text { Tiruchirapalli district, } \\
\text { Tamilnadu. }\end{array}$ & $\begin{array}{l}\text { A cluster randomised } \\
\text { trial with two months } \\
\text { follow up. }\end{array}$ & $\begin{array}{l}\text { Group: } \\
\text { Two sessions of health } \\
\text { education was offered } \\
\text { by a health } \\
\text { professional, five weeks } \\
\text { apart, along with self- } \\
\text { help material on } \\
\text { tobacco cessation to } \\
\text { intervention group. The } \\
\text { control group received } \\
\text { only self-help material. }\end{array}$ & $\begin{array}{l}\text { - Attendance in first } \\
\text { intervention session: } \\
88.5 \% \text {; second } \\
\text { intervention session: } \\
60.5 \% \text {. The follow-up } \\
\text { rates for intervention } \\
\text { and control arms were } \\
90.5 \% \text { and } 92.5 \% \text {, } \\
\text { respectively. }\end{array}$ & $\begin{array}{l}\text { At } 2 \text { months: } \\
\text { - Self-reported point } \\
\text { prevalence abstinence: } \\
13 \% \text { (intervention), 6\% } \\
\text { (control) } \\
\text { - Quit attempt: } 27 \% \\
\text { (intervention), 20\% } \\
\text { (control) } \\
\text { - Harm reduction: 22\% } \\
\text { (intervention) 9\% } \\
\text { (control) }\end{array}$ \\
\hline $\begin{array}{l}\text { 7. Government of } \\
\text { India smokeless } \\
\text { tobacco campaign } \\
\text { (Murukutla N et al. } \\
\text { 2011): Tobacco use }\end{array}$ & $\begin{array}{l}\text { Individuals aged 16-50 } \\
\text { years in urban and } \\
\text { rural areas who are } \\
\text { current smokeless } \\
\text { tobacco users and } \\
\text { have access to mass } \\
\text { media (television or } \\
\text { radio) }\end{array}$ & $\begin{array}{l}\text { The six weeks } \\
\text { campaign (November } \\
\text { and December 2009) } \\
\text { was evaluated with a } \\
\text { nationally } \\
\text { representative } \\
\text { household survey of } \\
2898 \text { smokeless } \\
\text { tobacco users during } \\
20 \text { December } 2009 \text { to } \\
10 \text { January } 2010 \text {. }\end{array}$ & $\begin{array}{l}\text { Population: } \\
\text { - An oral cancer } \\
\text { surgeon from a tertiary } \\
\text { care hospital in } \\
\text { Mumbai described the } \\
\text { serious illnesses and } \\
\text { disfigurement of his } \\
\text { patients, caused by } \\
\text { cancers resulting from } \\
\text { use of smokeless } \\
\text { tobacco. }\end{array}$ & $\begin{array}{l}\text { Screening interviews } \\
\text { were completed in } \\
92 \% \text { of the } \\
\text { respondents }\end{array}$ & $\begin{array}{l}\text { - Awareness of the } \\
\text { campaign: 63\% } \\
\text { (smokeless-only users), } \\
\text { 72\% (dual users) } \\
\text { - Concern about their } \\
\text { habit: } 75 \% \text { (smokeless- } \\
\text { only users), 77\% (dual } \\
\text { users) }\end{array}$ \\
\hline
\end{tabular}

Abbreviations: T2DM Type 2 Diabetes Mellitus; IGT Impaired Glucose Tolerance; IFG Impaired Fasting Glucose; RCT Randomised Controlled Trial; LSM Life Style Modification; FBG Fasting Blood Glucose; BP Blood Pressure.

age-adjusted prevalence of T2DM (fasting blood glucose $>126 \mathrm{mg} / \mathrm{dl}$ or on medication) for all of India, the prevalence in Kerala ranged by gender and area from $12.3 \%$ among urban men to $22.2 \%$ among rural women. The state average is $14.3 \%$ for men and $17.8 \%$ for women. Respective figures are $51.4 \%$ and $61.5 \%$ for hypercholesterolemia (total cholesterol $\geq 200 \mathrm{mg} / \mathrm{dl}$ ); $33.9 \%$ and $31.6 \%$ for hypertension (JNC VII); and 23.9\% and 37.5\% for overweight $\left(\mathrm{BMI} \geq 25.0 \mathrm{~kg} / \mathrm{m}^{2}\right)$ [30].

\section{Health behaviours}

Smoking prevalence in Kerala is $28 \%$ among adult men (24\% all India) [36], but almost non-existent among women. Unhealthy dietary habits are difficult to measure and compare due to the differences in definitions and the wide regional variation in composition of foods and diet found in India. Import-export data and national consumption and expenditure surveys suggest that more traditional (healthier) dietary patterns are being replaced by energydense (unhealthier) foods and beverages [37]. Between 1973 and 2005, energy derived from fats in India increased by $6 \%$ while energy derived from carbohydrates decreased by $7 \%$. However the overall decline in energy from carbohydrates masked important and more specific changes; intake of coarse cereals, pulses, fruits and vegetables is inadequate and decreasing while consumption of refined carbohydrates, sugars, oils, fats, meat products and salt is increasing [37].

Physical inactivity and sedentariness among both genders is very common in India. Moreover, physical activity is related to occupation with hardly any reported spare-time 
activity [38]. In rural India, over 90\% of the population report no vigorous or moderate physical activity during leisure-time [39]. Surprisingly, over $80 \%$ report no moderate or vigorous activity during work as well. The explanation for this is that even among those engaged in manual labour, physical activity does not really reach the required levels as work availability is erratic and seasonal and physical activity during non-work or leisure time is almost nil. Older or urban individuals, and women report more sedentary behaviour [40]. Apart from sleeping, TV viewing is the main spare-time activity [40,41]. Figures for different types of physical activity in Kerala are from early 2000, when the proportion of adults (30-70 yrs) physically inactive was $31 \%$ during work, $74 \%$ during leisure-time, and $39 \%$ during travel [42]. However, a study conducted in 2012 suggests considerably higher figures for leisure-time inactivity (98\%) [Mathews E, unpublished data]. Indirect evidence from national consumption surveys (2009-2010) also reflects this high sedentariness, as Keralites spend five times more money on TVs, 10-15 times more on motorcycles and 430-1250 times more on cars as compared to the rest of India [43].

Determinants of health behaviours have been little studied in India. A quantitative study on an urban population in Southern India reported low levels of knowledge regarding the benefits of healthy lifestyle, causes of diabetes, and measures to prevent or manage the disease, especially among women, labourers and unskilled workers, and those with lower education [44]. Management of diabetes is inadequate, not only due to poor medical control [45], but also to factors such as people's reluctance to share information of their illnesses even with significant others [46].

A study conducted in 2012 in Kerala identified several factors positively associated with physical activity, including role models and support among family, friends and neighbours; knowledge and advice from professionals; and presence of risk factors or chronic conditions in self or family. Environmental factors - poor access to facilities and heavy traffic - had negative associations [Mathews E, Pratt M \& Thankappan KR, unpublished data].

Only a few studies have reported on determinants of dietary behaviours among Indians. Negligible associations were found between diet and social cognitions such as self-efficacy and outcome expectations [47,48]. For example, Sharma and colleagues observed a small but significant positive association between self-efficacy and eating of fruit and vegetables. Suggested explanations for the low associations were high dependency on family in health behaviour decisions [47] and a tendency to fatalism [48].

Qualitative findings from a recent large interview study from Kerala reveal many ways in which the culture enforces unhealthy lifestyle; influencing dietary practices, physical activity, as well as the taking of medications. "A protruding belly speaks of a life of embodied satisfaction - good social relationships, status, success and health" [46], p. 270. Even amidst worry about health and recognition of the risks of unhealthy eating, dietary adjustments are not made because refusing food would be seen as an expression of anger or annoyance, or as a sign of illness. As a compromise, "taking medicines (...) is palatable because it doesn't disrupt the flow of food, care, love and pleasure in the households" [46], p. 270. Furthermore, leisure-time physical activity is seen as harmful in depleting one from energy needed for work, and it is especially discouraged among females who should focus on household chores and cooking instead [46]. This expectation is so strong that it prevails even in the younger generation after immigration into a culture that emphasizes fitness [49].

\section{Community-based interventions}

While a lot of recent medical and epidemiologic research in India has focused on NCDs [50], only a small proportion of the published studies have involved non-pharmacological interventions and only a few of these have included controlled study designs [51]. The seven interventions described in Table 1 targeted both normal population and high risk or diseased individuals, in clinical settings and 'real world' community settings. Only two of the studies $[52,53]$ used a randomised controlled trial design, many lacked a control group [22,54-56] and none reported an explicit theory-base for behaviour change despite evidence supporting the use of theory [57]. Characteristic of many studies is inclusion of multiple components operating on different levels - individual, group, community and population - a factor likely to have influenced the outcomes positively [58]. The Diabetes Prevention and Management programme is one prime example combining community and individual empowerment. It was participatory, and included village leaders, peer educators and residents. Despite a short 7-month duration, the intervention outcomes were impressive in terms of fasting blood glucose levels across healthy, high risk and T2DM individuals. The work site intervention programme on CVD risk factors [59] also operated on multiple levels and achieved positive outcomes on multiple risk factors and health behaviours. Overall, the changes found in health behaviours and risk factors were small to moderate, but tended to be greater among those with higher risk. Furthermore, most studies had short follow-ups, insufficient to determine long-term maintenance of the outcomes.

The public health effect of these programmes is determined as much by their reach to the target population as by their effectiveness. Most studies (Table 1) show high response rates among those invited to the study, but total reach is rarely reported. As an exception, Krishnan et al. [55] reported a $25 \%$ reach for their community programme 
in spite of a multi-pronged approach and mass awareness campaigns.

\section{Policy document review}

India's history of national health policy and strategies addressing NCDs is a recent one. It started with the principal comprehensive law governing tobacco control in India, the Cigarettes and Other Tobacco Products (Prohibition of Advertisement and Regulation of Trade and Commerce, Production, Supply and Distribution) Act (COTPA), 2003 [60]. However, poor implementation and monitoring prevented the public from enjoying full benefits of the law [61]. In 2004, India became a party to the WHO-Framework Convention on Tobacco Control (FCTC), subsequently leading to the National Tobacco Control Programme (NTCP, 200712) [62], a Government initiative to facilitate the implementation of anti-tobacco laws, bring about greater awareness on the harmful effects of tobacco, sensitize all the stakeholders and fulfill the obligations under the WHO-FCTC. Kerala joined the programme in the first wave of the roll out.

From the perspective of T2DM prevention, two subsequent Government initiated programmes are particularly significant: the National Rural Health Mission (NRHM) [63] launched in 2005, and the National Programme for Prevention and Control of Cancer, Diabetes, Cardiovascular Diseases and Stroke (NPCDCS) [64] in 2008. The NRHM aims at improving access to quality health care. The programme integrates Family Welfare and National Disease Control Programmes, incorporates village health workers called Accredited Social Health Activists (ASHA) to the programme and forms Health and Sanitation Committees at village, block and district level.

The pilot phase of the NPCDCS was launched in Kerala (Thiruvananthapuram district) in 2008, with the aim to cover all districts by 2017. The NPCDCS combines population and high risk approaches. Mass media campaigns to raise public awareness are conducted by the state NCD cells. The high-risk approach includes opportunistic screening at health care settings, patient education and risk factor monitoring by nurses and health workers, lifestyle counseling by qualified counselors, and improved medical care and supervision by medical doctors [64]. Since the implementation is currently ongoing, no evaluations have been done so far. Legislation or recommendations and responsible implementation agents for tobacco use and diet and physical activity from the documents are listed in Table 2.

Together, these three - national policies addressing tobacco; the NRHM to improve access to health care; and the NPCDCS that includes broad approaches to prevention - provide a base of concerted government, health sector, and community campaigns to improve health care and to promote the personal behaviours linked to prevention and disease management.

\section{Focus groups}

Content analysis revealed two main themes (Table 3): (1) What to intervene on with respect to behavioural targets and their determinants? (2) How to intervene in terms of preferences with respect to programme implementation? These themes and their sub-themes with views that emerged from the participants reveal a general interest to learn more and a common understanding that unhealthy lifestyle is related to a higher risk. However, they also showed misunderstandings concerning medication. Furthermore, perceptions related to risk as well as to outcomes of and self-efficacy in lifestyle change were generally low. Low male participation was not only an issue for the focus group study where most participants were females, but it was also indicated for village meetings, and the participants expected it to apply to any intervention as well.

\section{Discussion}

In this section, we provide a summary and synthesis of the findings, discuss the main strengths and limitations of the needs assessment, and outline the implications for designing a diabetes prevention programme for the rural setting of Kerala.

\section{Summary and synthesis of main findings}

The findings on clinical risk factors and disease, and related lifestyle behaviours with their environmental and individual determinants, as well as main characteristics of current policies, programmes and interventions to prevent non-communicable diseases in India are summarised in Figure 1.

Prevalence of clinical and anthropometric risk factors is very high and increasing in the whole of India, and Kerala is the most advanced state in the transition. The changes are largely attributable to lifestyle, which is rapidly changing towards unhealthier patterns. While the unhealthy dietary patterns and sedentary lifestyle are typical for both genders, they are more common among women, which is reflected in women's higher prevalence of T2DM [30]. Furthermore, sedentariness related to work, leisure-time and commuting applies not only in urban India but is also typical to the rural areas $[39,65]$.

Many of the environmental determinants for unhealthy behaviours, e.g., accessibility, availability, and cultural values and norms are likely linked to each other. Furthermore, they probably contribute to many personal determinants such as low self-efficacy for behaviour change in the context of the strong influences of family decision-making and norms. Taking the environmental determinants as primary targets for intervention may not be feasible. However, the personal determinants are not sufficient targets alone, either. Rather, it may be unrealistic to expect bet ter health behaviour outcomes, unless, the intervention 
Table 2 Tobacco use, diet and physical activity recommendations and their implementation

\begin{tabular}{|c|c|c|}
\hline Year & Recommendations & Implementing agency \\
\hline \multicolumn{3}{|l|}{ TOBACCO USE } \\
\hline \multirow[t]{5}{*}{2003} & $\begin{array}{l}\text { Cigarettes and Other Tobacco Products Act (COTPA) 2003: } \\
\text { - Prohibition of smoking in public places } \\
\text { - Prohibition of advertisement of cigarettes and other } \\
\text { tobacco products }\end{array}$ & \multirow[t]{5}{*}{$\begin{array}{l}\text { The Department of Health and Family Welfare in each state } \\
\text { is primarily responsible for implementation in coordination } \\
\text { with other departments, authorised officers and various } \\
\text { other stakeholders. }\end{array}$} \\
\hline & $\begin{array}{l}\text { - Prohibition of sale of tobacco products to minors } \\
\text { (below } 18 \text { years of age) }\end{array}$ & \\
\hline & - Prohibition of sale of tobacco products by minors & \\
\hline & $\begin{array}{l}\text { - Prohibition of sale of tobacco products within } 100 \\
\text { yards of the educational institutions } \\
\text { - Specified health warnings on tobacco products }\end{array}$ & \\
\hline & $\begin{array}{l}\text { - Testing of tobacco products for their harmful } \\
\text { contents and emissions }\end{array}$ & \\
\hline \multirow[t]{12}{*}{$2007-2012$} & $\begin{array}{l}\text { Programme components of National Tobacco Control } \\
\text { Programme (NTCP): }\end{array}$ & \multirow[t]{12}{*}{$\begin{array}{l}\text { NTCP to support implementation with national, state and } \\
\text { district level actions and actors }\end{array}$} \\
\hline & National level: & \\
\hline & - Mass media campaigns to create public awareness & \\
\hline & - Establishment of tobacco testing labs & \\
\hline & $\begin{array}{l}\text { - Mainstreaming the programme components as part } \\
\text { of the health delivery mechanism under the overall } \\
\text { NRHM framework }\end{array}$ & \\
\hline & $\begin{array}{l}\text { - Mainstreaming research and training on alternate } \\
\text { crops and livelihoods and monitoring and evaluation } \\
\text { including surveillance }\end{array}$ & \\
\hline & State level: & \\
\hline & - Establishment of a tobacco control cell & \\
\hline & District level: & \\
\hline & - Tobacco control centres & \\
\hline & - Information, Education and Communication activities & \\
\hline & - Training of professionals & \\
\hline \multicolumn{3}{|l|}{ DIET } \\
\hline \multirow[t]{7}{*}{2008 (pilot phase) } & $\begin{array}{l}\text { Guidelines by National Programme for Prevention and } \\
\text { Control of Diabetes, Cardiovascular diseases and Stroke } \\
\text { (NPDCS)* }\end{array}$ & \multirow[t]{7}{*}{ Ministry of Health and Family Welfare, Govt. of India } \\
\hline & $\begin{array}{l}\text { - Increase intake of green leafy vegetables and fresh } \\
\text { fruits. }\end{array}$ & \\
\hline & $\begin{array}{l}\text { - Consume less salt; avoid adding or sprinkling salt to } \\
\text { cooked and uncooked food. }\end{array}$ & \\
\hline & $\begin{array}{l}\text { - Preparations that are high in salt and need to be } \\
\text { moderated are: Pickles, chutneys, sauces and } \\
\text { ketchups, papads, chips and salted biscuits, cheese } \\
\text { and salted butter, bakery products and dried salted } \\
\text { fish. }\end{array}$ & \\
\hline & $\begin{array}{l}\text { - Restrict all forms of free sugars and refined } \\
\text { carbohydrates for example biscuits, breads, naan, } \\
\text { kulchas, cakes, and so on. }\end{array}$ & \\
\hline & $\begin{array}{l}\text { - Steamed and boiled food should be preferred over } \\
\text { fried food. }\end{array}$ & \\
\hline & - Have fresh lime water instead of carbonated drinks. & \\
\hline
\end{tabular}


Table 2 Tobacco use, diet and physical activity recommendations and their implementation (Continued)

\begin{tabular}{|c|c|c|}
\hline & \multicolumn{2}{|l|}{$\begin{array}{l}\text { - Avoid eating fast or junk foods and aerated drinks. } \\
\text { Instead of fried snacks, eat a fruit. }\end{array}$} \\
\hline & \multicolumn{2}{|l|}{$\begin{array}{l}\text { - In practice, it is best to use mixture of oils. Either buy } \\
\text { different oils every month or cook different food } \\
\text { items in different oils. Oils that can be mixed and } \\
\text { matched are mustard oil, soya bean oil, groundnut oil, } \\
\text { olive oil, sesame oil, and sunflower oil. }\end{array}$} \\
\hline & \multicolumn{2}{|l|}{$\begin{array}{l}\text { - Ghee, vanaspati, margarine, butter and coconut oil are } \\
\text { harmful and should be moderated. }\end{array}$} \\
\hline & \multicolumn{2}{|l|}{$\begin{array}{l}\text { - If you are a non-vegetarian, try to take more of fish } \\
\text { and chicken. They should not be fried. Red meat } \\
\text { should be consumed in small quantities and less } \\
\text { frequently. }\end{array}$} \\
\hline & \multicolumn{2}{|l|}{ - Eat variety of foods to ensure a balanced diet } \\
\hline \multirow[t]{15}{*}{2010} & Guidelines by National Institute of Nutrition (NIN) & \multirow{15}{*}{$\begin{array}{l}\text { These guidelines were proposed by the National Institute } \\
\text { of Nutrition, Hyderabad which works under the aegis of } \\
\text { Indian Council of Medical Research, Ministry of Health and } \\
\text { Family Welfare, Govt. of India }\end{array}$} \\
\hline & $\begin{array}{l}\text { - Combine different food groups to obtain a well- } \\
\text { balanced diet. Recommended balanced diet for adults } \\
\text { with moderate physical activity (for reference men } \\
\text { and women weighing } 60 \text { and } 55 \mathrm{~kg} \text { respectively): net } \\
\text { energy (kcal/day): } 2730 \text { (men), } 2230 \text { (women); Fats } \\
\text { and oils (visible fat): } 5 \mathrm{gX6} \text { (men), } 5 \mathrm{~g} \times 5 \text { (women); } \\
\text { Sugar: } 5 \mathrm{~g} \times 6 \text {; Milk and milk products: 100gX3; Pulses: } \\
\text { 30gX3 (men), 30gX2.5 (women); Vegetables (excluding } \\
\text { roots and tubers): 100gX3; Fruits: 100gX1; Cereals and } \\
\text { millets: } 30 \mathrm{gX15} \text { (men), 30gX11 (women). }\end{array}$ & \\
\hline & $\begin{array}{l}\text { - Ensure provision of extra food and healthcare to } \\
\text { pregnant and lactating women. }\end{array}$ & \\
\hline & $\begin{array}{l}\text { - Promote exclusive breastfeeding for six months and } \\
\text { encourage breastfeeding till two years. }\end{array}$ & \\
\hline & $\begin{array}{l}\text { - Feed home based semi-solid foods to the infant after } \\
\text { six months. }\end{array}$ & \\
\hline & $\begin{array}{l}\text { - Ensure adequate and appropriate diets for children } \\
\text { and adolescents in health and sickness. }\end{array}$ & \\
\hline & $\begin{array}{l}\text { - Ensure moderate use of edible oils and animal foods } \\
\text { and less use of ghee, vanaspati, and so on. }\end{array}$ & \\
\hline & $\begin{array}{l}\text { - Overeating should be avoided to prevent overweight } \\
\text { and obesity. }\end{array}$ & \\
\hline & $\begin{array}{l}\text { - Restrict salt intake to minimum, should not exceed } 6 \\
\text { g per day. }\end{array}$ & \\
\hline & $\begin{array}{l}\text { - Ensure safe and clean foods and practice right } \\
\text { cooking methods and healthy eating habits. }\end{array}$ & \\
\hline & $\begin{array}{l}\text { - Drink plenty of water and take beverages in } \\
\text { moderation. A normal healthy person needs to drink } \\
\text { about } 8 \text { glasses ( } 2 \text { litre) of water per day. }\end{array}$ & \\
\hline & $\begin{array}{l}\text { - Minimize the use of processed foods rich in salt, sugar } \\
\text { and fats. The intake of trans-fatty acids should not } \\
\text { exceed } 2 \% \text { of energy intake. }\end{array}$ & \\
\hline & $\begin{array}{l}\text { - Include micronutrient rich foods in the diets of elderly } \\
\text { people for them to be fit and active. }\end{array}$ & \\
\hline & - Eat plenty of vegetables and fruits. & \\
\hline & $\begin{array}{l}\text { - Exercise regularly and be physically active to maintain } \\
\text { ideal body weight. }\end{array}$ & \\
\hline
\end{tabular}


Table 2 Tobacco use, diet and physical activity recommendations and their implementation (Continued)

\begin{tabular}{|c|c|c|}
\hline \multicolumn{3}{|l|}{ PHYSICAL ACTIVITY } \\
\hline \multirow[t]{11}{*}{2008 (pilot phase) } & Guidelines by the NPCDCS* & \multirow{11}{*}{$\begin{array}{l}\text { Ministry of Health and Family welfare, Govt. of India with } \\
\text { WHO collaboration }\end{array}$} \\
\hline & $\begin{array}{l}\text { - Physical activity is a key determinant of energy } \\
\text { expenditure. }\end{array}$ & \\
\hline & $\begin{array}{l}\text { - Regular exercise is important for promoting weight } \\
\text { control or weight loss. }\end{array}$ & \\
\hline & $\begin{array}{l}\text { - Exercise regularly (moderate to vigorous) for 5-7 days } \\
\text { per week; start slowly and work up gradually. }\end{array}$ & \\
\hline & $\begin{array}{l}\text { O At least } 30 \text { min (accumulated) of physical activities } \\
\text { per day for cardiovascular disease protection. }\end{array}$ & \\
\hline & O $45 \mathrm{~min} /$ day (accumulated) for fitness. & \\
\hline & O 60 min/day (accumulated) for weight reduction. & \\
\hline & - Discourage spending long hours in front of television. & \\
\hline & $\begin{array}{l}\text { - Encourage outdoor activities like cycling, gardening } \\
\text { and so on. }\end{array}$ & \\
\hline & $\begin{array}{l}\text { - A minimum } 30-45 \text { min brisk walk/physical activity of } \\
\text { moderate intensity improves overall health. }\end{array}$ & \\
\hline & $\begin{array}{l}\text { - Include 'warm-up' and 'cool- down' periods, before } \\
\text { and after exercise regimen. }\end{array}$ & \\
\hline \multirow[t]{9}{*}{2010} & Guidelines by NIN & \multirow{9}{*}{$\begin{array}{l}\text { Guidelines were proposed by the National Institute of } \\
\text { Nutrition, Hyderabad which works under the aegis of } \\
\text { Indian Council of Medical Research, Ministry of Health and } \\
\text { Family Welfare, Govt. of India }\end{array}$} \\
\hline & $\begin{array}{l}\text { - Physical activity is essential to maintain ideal body } \\
\text { weight by burning excess calories and is of vital } \\
\text { significance for health and prevention of diseases. }\end{array}$ & \\
\hline & $\begin{array}{l}\text { - Physical activity is essential for the reduction of } \\
\text { morbidity and mortality due to several chronic } \\
\text { diseases and may reduce the risk of falls and injuries } \\
\text { in the elderly. }\end{array}$ & \\
\hline & - Exercise is a prescriptive medicine. & \\
\hline & - Move your body as much as you can. & \\
\hline & $\begin{array}{l}\text { - Physical activity is a major modifiable risk factor in } \\
\text { reduction of non-communicable chronic diseases. }\end{array}$ & \\
\hline & $\begin{array}{l}\text { - Recommended to carry out at least } 45 \text { min of } \\
\text { moderate intensity activity, which may reduce the risk } \\
\text { of chronic diseases. }\end{array}$ & \\
\hline & $\begin{array}{l}\text { - To lose weight } 60 \text { min of moderate to vigorous } \\
\text { intensity physical activity may be taken for most of } \\
\text { the days in a week. }\end{array}$ & \\
\hline & $\begin{array}{l}\text { - Children and teenagers need at least } 60 \text { min of } \\
\text { physical activity every day. In the case of pregnant } \\
\text { women } 30 \text { min or more of moderate-intensity } \\
\text { physical activity every day is recommended. }\end{array}$ & \\
\hline
\end{tabular}

* The programme was launched in 10 states (including Kerala) and 10 districts as National Programme for Prevention and Control of Diabetes, Cardiovascular Disease and Stroke (NPDCS) in 2008. In 2010-11, when it was scaled up to 21 states and 21 districts, a cancer component was added and its name was changed to National Programme for Prevention and Control of Cardiovascular Disease, Diabetes, Cancer and Stroke (NPCDCS).

addresses the influence of families and neighbours as well as the culturally inscribed roles of men and women in their families and communities.

Intervention research in India suggests that risk reduction is possible, but current evidence available from community settings is rather limited. In the absence of supports available for such programmes in developed countries (e.g., intensive schedules; special low calorie diets; extra resources for participants; free access to supporting facilities like gyms) [5,6], the risk reduction from intervention studies in India and similar settings will likely be more moderate. Previous research has established models in India for multi-level strategies including mass awareness campaigns, community empowerment, and individual empowerment [22,52-56,59]. However, the low reach of interventions in the community is a challenge, especially among those with higher needs, including rural people $[55,66]$. Another challenge is related to the use of relevant socio-behavioural theories, which is currently rare in interventions conducted in India. While studies from developed 
Table 3 Responses of the focus group discussions as themes and sub-themes with descriptions

Theme 1: What to intervene on with respect to behavioural targets and their determinants?

\begin{tabular}{l} 
Sub-themes Description and quotes \\
\hline 1. Knowledge General interest to know more about diabetes and its \\
and beliefs of prevention. \\
diabetes
\end{tabular}

Theme 2: How to intervene in terms of preferences with respect to programme implementation?

Sub-themes

1. Trusted sources of health information or potential intervention agents

Description and quotes

- Health centers.

- Physicians, health care providers.
- Grass root level non-physician health workers.

- Accredited Social Health Activists (ASHAs).

- 'Kudumbasree' (local women's self-help groups)

2. Risk factors $\cdot$ Strong family history and the modern lifestyle.

- Unhealthy dietary habits including regular consumption of foods rich in fats and sugar like sweets, roots like tapioca and certain fruits, particularly sweet bananas like 'rasakathali'. High consumption of pastries and snacks as parts of urban lifestyle.

- Physical inactivity, particularly in sedentary occupations and in urban environment. "People just don't walk now-a-days."

- Long-term medications: "Since I am on a lot of medication, I expect that I may get it. I have read in articles that those who take medicines for blood pressure and other things have a higher chance of getting such illnesses."

- Protective factors other than healthy food habits e.g., "using no sugar in tea for the last 15 years" - rarely mentioned. \begin{tabular}{ll}
\hline 3. Risk & - No awareness of pre-diabetes status. \\
perception & - Diabetes risk perceived higher for women, a group \\
& seen as less physically active, with a tendency to over
\end{tabular} eat and to ignore early symptoms.

- Perceived own risk:

i. Little to no risk: Participants, who perceived their food habits were healthy; had no family history; or had faith that regardless of habits, they were simply not at risk. "I don't believe in any of this. I don't feel I have any risk. I still need double sugar in my tea." ii. Fifty percent or more risk: Participants who already had a related illness like hypertension or myocardial infarction; or hypertensive or anti-cholesterol medication, perceived to contribute to high blood sugar; or who had significant family history. "I expect a $50 \%$ risk as I am a hypertensive for the last 18 years and have been on medication and I had a heart attack 10 years back."

iii. Don't know: Not able or were not willing to speculate about their risk.

4. Outcome - Diabetes has no cure, but can be controlled with expectations oral medicines, injections, dietary and other lifestyle changes.

- Low outcome expectations for lifestyle modification after the pre-clinical or very early stages of the disease: "You can only control it or decrease it. When food is controlled along with treatment, up to $80 \%$ can be controlled. Once you get the illness, you have no choice but to go for treatment."

\author{
2. Use and acceptance - Telephone used by all and highly accepted for \\ of Information \\ Communication \\ Technology (ICT) \\ practical organization of meetings. \\ - Mobile phones used and accepted for incoming calls. \\ - SMS used but not accepted. \\ - Internet not used.
}

3. Preferences for intervention delivery

\author{
"If meeting points or places can be identified for \\ each locality and the intervention is done as a \\ group, it is better. It should be a place where people \\ in that area can walk to or access easily." \\ - Regarding low male participation to regular \\ village meetings (Gramsabha), "active men should \\ invite other men". \\ - Venue: \\ a. Easy access. \\ b. Within walking distance. \\ c. Health centres, reading rooms or anganwadis. \\ d. Participants' homes. \\ - Format: \\ a. Group of 10-25 participants, important for \\ generating different ideas that would benefit the \\ whole group. \\ b. Including at least two people per family and \\ neighbours. Women might need permission from \\ their husbands. \\ - Time. \\ a. Duration $1-1.5 \mathrm{~h}$ \\ b. Once-a-week. \\ c. On holidays. \\ d. When children are at school (for housewives).
}

\footnotetext{
5. Self- $\quad$ A collective low self-efficacy regarding the ability to

efficacy make and sustain changes in lifestyle. "I don't think it is possible to make modifications in our lifestyle. No matter what you say, it will just continue like this."

- Dietary habits not within individual control.

- Cultural norms such as "fruits other than bananas
} 
belong to children's diet only" and collective household

decision-making guide dietary practices.

- Physical activity is related to everyday chores, like walking to the market, or to job like farm work, not to leisure-time. "I am a driver working in the Gulf. When I come home for vacation, I do farming for four hours every day. I also have cows, so I get enough exercise. When I am in the Gulf, there is no time to walk or for any other exercise." For men, availability of time is a barrier while for women both time and space restrict the possibilities to be physically active. "I used to do Yoga in the mornings. (...) When we go to the room, there should be no one else there. We need privacy. Slowly, it has become difficult to find such a time and space so, now I don't do it anymore".

"I have heard that walking is good. But we have to start kitchen work at 6.30 in the morning, so when can we walk?" "We can't go out of our own compound to walk. If we have space in our own backyard, it will work." - Quitting tobacco is hard because of social pressure. "I have quit several times, each time for varying duration (...) Inevitably, I will see some of my friends smoking or they will offer a cigarette and I will start smoking again." - Professional help is not sought for quitting. "If we want to stop smoking, we can decrease slowly not suddenly. If you smoke 10, you can make it 5, then 2 and then stop." -Women can only influence men's use of tobacco by asking them not to smoke inside the homes.

countries show that use of theory increases intervention effectiveness [57], the existing theories have been neither developed nor adequately tested with Indian populations to determine their usefulness in India. The qualitative findings from our needs assessment suggest that theoretical constructs such as self-efficacy and outcome expectations will likely have validity across cultures. However, their application in collectivist and family-oriented cultures will need further development in order for them to guide efforts at promoting behaviour change in India.

National programmes for tobacco control and prevention and control of major NCDs including T2DM have also been implemented in the state of Kerala. While the concerned government bodies have taken disease prevalence

\begin{tabular}{|c|c|c|c|}
\hline \multirow[b]{4}{*}{$\begin{array}{l}\text { CLINICAL RISK- } \\
\text { FACTORS AND DISEASES: }\end{array}$} & \multirow[b]{3}{*}{$\begin{array}{r}\text { NCD-RELATED } \\
\text { HEALTH BEHAVIOURS: }\end{array}$} & \multirow[b]{2}{*}{$\begin{array}{r}\text { DETERMINANTS OF } \\
\text { NCD-RELATED HEALTH BEHAVIOUR: }\end{array}$} & $\begin{array}{r}\text { ACTIONS AND FACTORS } \\
\text { RELATED TO NCD PREVENTION: }\end{array}$ \\
\hline & & & \multirow{3}{*}{$\begin{array}{l}\text { Policies and programs: } \\
\text { \& Programs provide key } \\
\text { recommendations and } \\
\text { guidelines, materials, training } \\
\text { and roles for health } \\
\text { professionals }\end{array}$} \\
\hline & & $\begin{array}{l}\text { Environmental determinants: } \\
\diamond \text { Unsafe roads, few sports facilities }\end{array}$ & \\
\hline & \multirow{3}{*}{$\begin{array}{l}\diamond \text { Change away from traditional eating } \\
\text { patterns, leading to increase in refined } \\
\text { carbohydrates, meat, fat; insufficient fruit } \\
\text { and vegetable intake }\end{array}$} & $\begin{array}{l}\diamond \text { Availability of and access to healthy foods } \\
\diamond \text { Cultural values and norms (including gender } \\
\text { roles) }\end{array}$ & \\
\hline High prevalence of: & & $\begin{array}{l}\diamond \text { Lack of social support for healthy lifestyle: } \\
\quad \text { family-members and other people discourage }\end{array}$ & $\begin{array}{l}\diamond \text { Relatively short history with no } \\
\text { evaluation on implementation }\end{array}$ \\
\hline$\diamond$ Hyper-cholesterolemia & & $\begin{array}{l}\text { physical activity and encourage unhealthy eating } \\
\diamond \text { Decision-making on health at family level } \\
\text { Personal determinants: }\end{array}$ & $\begin{array}{l}\text { and outcomes } \\
\text { Community-based interventions: }\end{array}$ \\
\hline$\diamond$ Hypertension & $\begin{array}{l}\diamond \text { Unhealthy diet and sedentary lifestyle } \\
\text { typical to both genders but more so to } \\
\text { women }\end{array}$ & $\begin{array}{l}\diamond \text { Low awareness and knowledge related to T2DM } \\
\diamond \text { Misconceptions related to traditional and } \\
\text { modern medication }\end{array}$ & $\begin{array}{l}\diamond \text { Multi-level strategies; Mass } \\
\text { awareness campaigns, } \\
\text { community empowerment }\end{array}$ \\
\hline$\diamond$ Overweight & $\diamond$ Smoking \& alcohol-use common among men & $\begin{array}{l}\diamond \text { Optimistic bias in risk perception } \\
\diamond \text { Low outcome expectations for behaviour change }\end{array}$ & $\diamond$ Need yet to overcome \\
\hline$\diamond \mathrm{T} 2 \mathrm{DM}$ & $\begin{array}{l}\diamond \text { Poor adherence to hypertension and } \\
\text { cholesterol lowering medication }\end{array}$ & $\begin{array}{l}\text { and T2DM prevention with lifestyle change } \\
\diamond \text { Low self-efficacy in behaviour change. }\end{array}$ & $\begin{array}{l}\text { problems of coverage and lack } \\
\text { of theory }\end{array}$ \\
\hline
\end{tabular}

Figure 1 Summary of findings from the needs assessment study. This figure summarizes the findings of the needs assessment for the Kerala Diabetes Prevention Programme through triangulation and synthesis of evidence from three major sources of information: research literature review, policy document review and focus group study. 
and morbidity and mortality patterns into consideration, the scientific basis for the proposed policies and programmes is not very clear in any of the accessed programme or policy documents. Moreover, their effectiveness has not been evaluated, thus limiting their usefulness to that of a positive reinforcer due to the launch of the mass awareness campaigns. In any case, these developments have prepared the ground for the development of NCD prevention programmes as well as promoting awareness among population and health professionals. In addition, their organizational infrastructure may provide local level resources to support intervention implementation by integration of many local agents such as village committees and village health workers like the ASHAs.

\section{Strengths and limitations}

This study not only provides a quite comprehensive assessment of needs but also of available capacities and supports for T2DM prevention in Kerala. The findings are derived from a systematic review of major intervention studies as well as epidemiological research on social and behavioural risk factors conducted in India. The evidence is triangulated with two other major sources of information, that is, a review of policy development in relation to the prevention and control of NCDs as well as, a focus group study. However, the search for relevant policy documents was confined to the Internet and it focuses primarily on national policies and programmes. Where possible, local experts in Kerala were used to fill any gaps in relation to policies developed and implemented in Kerala. Although the small number of focus groups and low participation rate is an important limitation, there was good consensus between our major findings and those of other qualitative and quantitative studies having bigger samples, thereby increasing the external validity of our findings [46-49].

\section{Implications for developing the community-based K-DPP Selection of behavioural targets}

Increasing the consumption of fruits and vegetables and reducing sugar-containing foods are important targets for diet. The concept that physical activity is an integral and vital part of all aspects of daily life, with contexts other than just the work environment, also needs to be promoted. Earlier T2DM programmes from developed countries did not focus on tobacco use because that was not yet recognised as a risk factor to T2DM. However, with the present knowledge [67] and high prevalence of tobacco use among men in Kerala, it needs to be addressed in K-DPP. Furthermore, proper use of medication and traditional remedies are also important behavioural issues to address.

\section{Main determinants to be addressed}

Risk perception and knowledge about risk factors need to be core starting points for the intervention, as both low awareness and important misconceptions related to these factors have been identified. Based on our results, it seems clear that little standard information is currently made available to people in India concerning risk of diabetes, its causes and what to do about this in order to reduce risk of progression to diabetes and its complications. Focus group responses indicated that many people perceived that progression to diabetes and going on to medications was inevitable, due to family and cultural influences, and hence, it was not really possible for the individual to do anything about this. A diabetes prevention programme should educate those at risk and their families regarding these issues and the importance of a healthy diet and physical activity for both improved prevention and control of diabetes.

When considering the psychosocial determinants of lifestyle change, it is important to emphasise the 'social' aspect and to adopt a more family- and community-oriented approach rather than the more individualistic approach, which has been generally used in North American and European programmes. Given the very high prevalence of hypertension, hypercholesterolemia and other associated cardio-metabolic conditions, a key message should also be that improving diet, increasing physical activity and reducing sedentariness to prevent diabetes are good health habits for the entire family to reduce risk of chronic conditions, and that this approach is not just relevant to the individual at risk of diabetes. When assessing risks and reappraising outcomes, participants should be helped to consider the implications for their families, and to set goals together with their family and others living in their household. Instead of focusing on individual control, the issues of over-eating and physical inactivity, and the identification of healthier lifestyle options need to be addressed collectively. By emphasising collective problem solving, i.e., by finding solutions to key barriers together, and by identifying collective ways for pursuing a healthier lifestyle and for providing social support to one another, individuals' low self-efficacy could be significantly enhanced. Community empowerment, which includes identification of key community leaders, citizens, organizations, volunteers and other resources, and supporting their role in creating social norms; and planning and developing local environments that would enable more healthy lifestyles will also, be an important enabler for individual empowerment.

\section{Intervention programme delivery}

A group format for programme delivery was emphasised among our participants due to practical reasons but also as a supportive measure. Groups can integrate naturally occurring societal influences into the programme and provide channels for development of key processes within communities [68]. However, this kind of family- and communityoriented approach will also inevitably require making at least some of the group sessions available to other family 
members and neighbours to attend and to be involved. Additionally, peer-to-peer influences could be developed naturally to provide encouragement and assistance in reaching those who otherwise might not avail themselves of the programme [68], especially males. Low participation by males is a major threat to this approach and to address this, will require effective strategies for recruiting and maximizing the attractiveness of this kind of intervention approach for them. All of these factors provide a strong rationale for a peer support model as has been recently proposed [68].

\section{Overall design of the study}

The intervention for the Kerala Diabetes Prevention Programme is being designed with a theoretical base (theories of self-regulation and social support $[16,21,68])$, which has been shown to improve the effectiveness of interventions. Due to the relatively sparse evidence related to community-based NCD intervention research in India, many of the proposed strategies are being adapted from relevant intervention programmes undertaken in other countries that include China, United States, Australia and Finland. However, we are now able to combine these with the key elements and steps generated from our systematic review and analysis of the Indian and Kerala contexts in particular; and the various community meetings that have been held to discuss these issues during the recent piloting phase of K-DPP. However, the proposed approach will emphasize community empowerment as this has emerged both from the literature review and the focus group study as being very important. The strategies for the intervention programme are being currently piloted and further modified before the main trial commences. Finally, the rapidly evolving national and state policies and programmes focused on NCD prevention and control are also expected to provide support for K-DPP by raising awareness. Having a shared mission and understanding of the primary goals and strategies of any intervention programme with the local agents including health professionals, will also help to improve the programme reach among those with the highest need for the K-DPP intervention; as well as to ensure support for the implementation and long-term sustainability of the programme.

\section{Conclusions}

The findings of this needs assessment study provide a strong basis for community-based diabetes prevention in the rural setting and culture of Kerala. They emphasize the significance of identifying key behavioural targets and their determinants; and to the importance of addressing cultural, community and family level factors in contrast to a more individualistic approach. They also suggest a more collectivistic approach for intervention delivery, with strong involvement of those at risk as well as their family and community members. These strategies along with the evolving support to be provided by national and regional policies and programmes to improve the prevention and control of NCDs will help the K-DPP achieve its goals as a feasible and effective intervention to prevent T2DM in rural India.

\section{Additional files}

\author{
Additional file 1: Criteria and search strategy used for research \\ literature search. \\ Additional file 2: Kerala Diabetes Prevention Programme - focus \\ group questions.
}

\section{Abbreviations \\ K-DPP: Kerala Diabetes Prevention Programme; T2DM: Type 2 Diabetes Mellitus; FGD: Focus group discussion; NCD: Non-communicable diseases; NRHM: National Rural Health Mission; NPCDCS: National Programme for control and prevention of Cancer, Diabetes, Cardiovascular Diseases and Stroke; ASHA: Accredited Social Health Activist.}

\section{Competing interests}

The authors declare that they have no competing interests.

\section{Authors' contribution}

MD: contributed to the conception and design of the study, conducted the research literature and policy document review, FGD data collection and analysis, conducted the evidence triangulation and synthesis, drafted as well as revised the manuscript; PA: conceptualised and designed the study, conducted the research literature and policy document review, conducted the evidence triangulation and synthesis, drafted as well as revised the manuscript; ST: conducted the research literature review, participated in evidence triangulation and synthesis, and revision of the manuscript; KRT: contributed to the conception and design of the study, participated in evidence triangulation and synthesis, and critically revised the manuscript; EBF: contributed to the conception and design of the study, participated in evidence triangulation and synthesis and critically revised the manuscript; NEP: participated in evidence triangulation and synthesis and revision of the manuscript; EM: participated in evidence triangulation and synthesis and revision of the manuscript; $\mathrm{BO}$ : conceptualised and designed the study, participated in evidence triangulation and synthesis, critically revised the manuscript and gave final approval of the version to be published. All authors read and approved the final manuscript.

\section{Acknowledgements}

Research reported in this publication was supported by the Kerala Diabetes Prevention Programme (K-DPP), funded by the National Health \& Medical Research Council, Australia (Grant Identification Number: 1005324); and by trainees who are supported by the ASCEND Programme (www.med.monash. edu.au/ascend), funded by the Fogarty International Centre of the National Institutes of Health (Award Number: D43TW008332). The content is solely the responsibility of the authors and does not necessarily represent the official views of these two funding agencies. We would also like to thank Dr. Pradeepkumar AS, Additional Director of Health Services (Public Health), Directorate of Health Services, Government of Kerala and Dr. Hafiz SA, State Nodal Officer (NCD), National Rural Health Mission, Kerala for verifying the current status in terms of implementation of the NCD-related national programmes in the state.

\section{Author details}

${ }^{1}$ Achutha Menon Centre for Health Science Studies, Sree Chitra Tirunal Institute for Medical Sciences and Technology, Trivandrum, Kerala, India. ${ }^{2}$ Division of Global Health (IHCAR), Department of Public Health Sciences, Karolinska Institutet, Nobels vag 9, Stockholm 171 77, Sweden. ${ }^{3}$ National Institute for Health and Welfare, Helsinki, Finland. ${ }^{4}$ School of Public Health and Preventive Medicine, Monash University, Melbourne, Australia. 
${ }^{5}$ Department of Health Behaviour and Health Education, Gillings School of Global Public Health, University of North Carolina at Chapel Hill, Chapel Hill, USA.

Received: 25 June 2012 Accepted: 16 January 2013 Published: 1 February 2013

\section{References}

1. International Diabetes Federation: Diabetes Atlas. 5th edition. Brussels, Belgium: International Diabetes Federation; 2011.

2. Mohan V, Deepa M, Deepa R, Shanthirani CS, Farooq S, Ganesan A, Datta M: Secular trends in the prevalence of diabetes and impaired glucose tolerance in urban South India - the Chennai Urban Rural Epidemiology Study (CURES-17). Diabetologia 2006, 49:1175-1178.

3. Ramachandran A, Wan Ma RC, Snehalatha C: Diabetes in Asia. Lancet 2010, 375:408-418.

4. Li G, Zhang P, Wang J, Gregg EW, Yang W, Gong Q, Li H, Li H, Jiang Y, An Y, Shuai Y, Zhang B, Zhang J, Thompson TJ, Gerzoff RB, Roglic G, Hu Y, Bennett PH: The long-term effect of lifestyle interventions to prevent diabetes in the China Da Qing Diabetes Prevention Study: a 20-year follow-up study. Lancet 2008, 371:1783-1789.

5. Tuomilehto J, Lindström J, Eriksson JG, Valle $\Pi$, Hämäläinen $H$, llanne-Parikka $P$, Keinänen-Kiukaanniemi S, Laakso M, Louheranta A, Rastas M, Salminen V, Uusitupa M, Finnish Diabetes Prevention Study Group: Prevention of type 2 diabetes mellitus by changes in lifestyle among subjects with impaired glucose tolerance. N Engl I Med 2001, 344:1343-1350.

6. Knowler WC, Barrett-Connor E, Fowler SE, Hamman RF, Lachin JM, Walker EA, Nathan DM, Diabetes Prevention Program Research Group: Reduction of the incidence of type 2 diabetes with lifestyle intervention or metformin. N Engl J Med 2002, 346:393-403.

7. Ramachandran A, Snehalatha C, Mary S, Mukesh B, Bhaskar AD, Vijay V, Indian Diabetes Prevention Programme (IDPP): The Indian diabetes prevention programme shows that lifestyle modification and metformin prevent type 2 diabetes in Asian Indian subjects with impaired glucose tolerance (IDPP-1). Diabetologia 2006, 49:289-297.

8. Kosaka K, Noda M, Kuzuya T: Prevention of type 2 diabetes by lifestyle intervention: a Japanese trial in IGT males. Diabetes Res Clin Pract 2005 67:152-162.

9. Alberti KG, Zimmet $P$, Shaw J: International diabetes federation: a consensus on Type 2 diabetes prevention. Diabet Med 2007, 24:451-463.

10. Crandall JP, Knowler WC, Kahn SE, Marrero D, Florez JC, Bray GA, Haffner SM, Hoskin M, Nathan DM, Diabetes Prevention Program Research Group: The prevention of type 2 diabetes. Nat Clin Pract Endocrinol Metab 2008, 4:382-393.

11. Eriksson KF, Lindgarde F: Prevention of type 2 (non-insulin-dependent) diabetes mellitus by diet and physical exercise. The 6-year Malmo feasibility study. Diabetologia 1991, 34:891-898.

12. Pan XR, Li GW, Hu YH, Wang JX, Yang WY, An ZX, Hu ZX, Lin J, Xiao JZ, Cao $H B$, Liu PA, Jiang XG, Jiang YY, Wang JP, Zheng $H$, Zhang $H$, Bennett PH, Howard BV: Effects of diet and exercise in preventing NIDDM in people with impaired glucose tolerance. The Da Qing IGT and Diabetes Study. Diabetes Care 1997, 20:537-544.

13. Herman WH, Hoerger TJ, Brandle M, Hicks K, Sorensen S, Zhang P, Hamman RF, Ackermann RT, Engelgau MM, Ratner RE, Diabetes Prevention Program Research Group: The cost-effectiveness of lifestyle modification or metformin in preventing type 2 diabetes in adults with impaired glucose tolerance. Ann Intern Med 2005, 142:323-332.

14. Ramachandran A, Snehalatha C, Yamuna A, Mary S, Ping Z: Costeffectiveness of the interventions in the primary prevention of diabetes among Asian Indians: within-trial results of the Indian Diabetes Prevention Programme (IDPP). Diabetes Care 2007, 30:2548-2552

15. Diabetes Prevention Program Research Group: Within-trial costeffectiveness of lifestyle intervention or metformin for the primary prevention of type 2 diabetes. Diabetes Care 2003, 26:2518-2523.

16. Absetz $P$, Valve R, Oldenburg B, Heinonen $H$, Nissinen A, Fogelholm $M$, et al: Type 2 diabetes prevention in the "real world": one-year results of the GOAL Implementation Trial. Diabetes Care 2007, 30:2465-2470.

17. Absetz $P$, Valve $R$, Oldenburg B, Heinonen $H$, Nissinen A, Fogelholm $M$, Ilvesmäki V, Talja M, Uutela A: Type 2 diabetes prevention in the real world: three-year results of the GOAL lifestyle implementation trial. Diabetes Care 2009, 32:1418-1420.
18. Kilkkinen A, Heistaro S, Laatikainen T, Janus E, Chapman A, Absetz P, Dunbar $\mathrm{J}$ : Prevention of type 2 diabetes in a primary health care setting. Interim results from the Greater Green Triangle (GGT) Diabetes Prevention Project. Diabetes Res Clin Pract 2007, 76:460-462.

19. Campbell M, Fitzpatrick R, Haines A, Kinmonth AL, Sandercock P, Spiegelhalter D, Tyrer P: Framework for design and evaluation of complex interventions to improve health. BMJ 2000, 321:694-696.

20. Campbell NC, Murray E, Darbyshire J, Emery J, Farmer A, Griffiths F, Guthrie $B$, Lester $\mathrm{H}$, Wilson P, Kinmonth AL: Designing and evaluating complex interventions to improve health care. BMJ 2007, 334:455-459.

21. Laatikainen T, Philpot B, Hankonen N, Sippola R, Dunbar JA, Absetz P, Reddy $P$, Davis-Lameloise N, Vartiainen E: Predicting changes in lifestyle and clinical outcomes in preventing diabetes: the greater green triangle diabetes prevention project. Prev Med 2012, 54:157-161.

22. Balagopal P, Kamalamma N, Patel TG, Misra R: A community-based diabetes prevention and management education program in a rural village in India. Diabetes Care 2008, 31:1097-1104.

23. Misra R, Balagopal P, Kamalamma N, Patel TG: Participatory Diabetes Prevention and Management Program in a Semi-Urban Village in India. In Proceedings of the $136^{\text {th }}$ Annual meeting and expo of the American Public Health Association held in San Diego, California on 25-28 October 2008. Washington DC, USA: Annual American Public Health Association (APHA); 2008.

24. Ali MK, Echouffo-Tcheugui J, Williamson DF: How effective were lifestyle interventions in real-world settings that were modeled on the Diabetes Prevention Program? Health Aff 2012, 31:67-75.

25. Puska P: From Framingham to North Karelia: from descriptive epidemiology to public health action. Prog Cardiovasc Dis 2010, 53:15-20.

26. Mittelmark MB, Hunt MK, Heath GW, Schmid TL: Realistic outcomes: lessons from community-based research and demonstration programs for the prevention of cardiovascular diseases. J Public Health Policy 1993, 14:437-462.

27. Bandura A: Health promotion by social cognitive means. Health Educ Behav 2004, 31:143-164.

28. Carver CS: Self regulation of action and affect. In Handbook of self-regulation: Research, theory and applications. New York: Guilford Press; 2004:13-39.

29. Oldenburg B, Absetz P: Lost in translation: overcoming the barriers to global implementation and exchange of behavioral medicine evidence. Transl Behav Med 2011, 1:252-255.

30. Thankappan KR, Shah B, Mathur P, Sarma PS, Srinivas G, Mini GK, Daivadanam M, Soman B, Vasan RS: Risk factor profile for chronic noncommunicable diseases: results of a community-based study in Kerala. India. Indian J Med Res 2010, 131:53-63.

31. Office of the Registrar General of India: Census of India: Provisional Population Totals: Kerala. Available at: http:/www.censusindia.gov.in/2011prov-results/paper2/prov_results_paper2_kerala.html (last accessed 11.02.2013).

32. Will JC, Galuska DA, Ford ES, Mokdad A, Calle EE: Cigarette smoking and diabetes mellitus: evidence of a positive association from a large prospective cohort study. Int J Epidemiol 2001, 30:540-546.

33. Soman CR, Shahulhameed S, Ramankutty V, Vijayakumar K, Kunjukrishnapillai R, Ajayan K, Sajikumar S, PROLIFE study group: Cohort profile: the PROLIFE study in Kerala India. Int J Epidemiol 2011, 40:10-14.

34. Graneheim UH, Lundman B: Qualitative content analysis in nursing research: concepts, procedures and measures to achieve trustworthiness. Nurse Educ Today 2004, 24:105-112.

35. World Health Organization: HIV triangulation resource guide: synthesis of results from multiple data sources for evaluation and decision-making. Available at: http://data.unaids.org/pub/Manual/2009/ 20090915_hiv_triangulation_resource_guide_en.pdf (last accessed: 11.02.2013).

36. Ministry of Health \& Family Welfare, Government of India: Global Adult Tobacco Survey (GATS) India Report 2009-2010. Available at: http://whoindia. org/EN/Section20/Section25_1861.htm (last accessed 16.06.2012).

37. Misra A, Singhal N, Sivakumar B, Bhagat N, Jaiswal A, Khurana L: Nutrition transition in India: secular trends in dietary intake and their relationship to diet-related non-communicable diseases. J Diabetes 2011, 3:278-292.

38. Yadav K, Krishnan A: Changing patterns of diet, physical activity and obesity among urban, rural and slum populations in north India. Obes Rev 2008, 9:400-408.

39. Ng N, Hakimi M, Van Minh H, Juvekar S, Razzaque A, Ashraf A, Masud Ahmed S, Kanungsukkasem U, Soonthornthada K, Huu Bich T: Prevalence of physical inactivity in nine rural INDEPTH Health and Demographic 
Surveillance Systems in five Asian countries. Global Health Action 2009, 2. doi:10.3402/gha.v2i0.1985.

40. Sullivan R, Kinra S, Ekelund U, Bharathi AV, Vaz M, Kurpad A, Collier T, Reddy KS, Prabhakaran D, Ben-Shlomo Y, Davey Smith G, Ebrahim S, Kuper H: Socio-demographic patterning of physical activity across migrant groups in India: results from the Indian migration study. PLoS One 2011, 6:e24898.

41. Tandon K, Kapoor S, Kapoor AK: Covariates and prevalence of obesity among adult north Indian population. Coll Antropol 2011, 35:305-311.

42. Sugathan TN, Soman CR, Sankaranarayanan K: Behavioural risk factors for Non communicable diseases among adults in Kerala, India. Indian J Med Res 2005, 127:555-563.

43. Ministry of Statistics and Programme Implementation, Government of India: National Sample Survey 66th Round (2009-2010). Available at: http://mospi. nic.in/mospi_new/upload/nss_report_541.pdf (last accessed 11.04.2012).

44. Murugesan N, Snehalatha C, Shobhana R, Roglic G, Ramachandran A: Awareness about diabetes and its complications in the general and diabetic population in a city in southern India. Diabetes Res Clin Pract 2007, 77:433-437.

45. Joshi SR, Das AK, Vijay VJ, Mohan V: Challenges in diabetes care in India: sheer numbers, lack of awareness and inadequate control. J Assoc Physicians India 2008, 56:443-450.

46. Wilson C: 'Eating, eating is always there': food, consumerism and cardiovascular disease. Some evidence from Kerala, south India. Anthropol Med 2010, 17:261-275.

47. Sharma M, Mehan MB, Surabhi S: Using Social Cognitive theory to predict obesity prevention behaviours among preadolescents in India. Int $Q$ Community Health Educ 2008-2009, 29:351-361.

48. Mehta P, Sharma M, Bernard A: Social cognitive theory as a predictor of dietary behavior and leisure time physical activity behavior in middleaged Asian Indian women residing in United States. Int Q Community Health Educ 2009-2010, 30:257-269.

49. Ramanathan S, Crocker PRE: The influence of family and culture on physical activity among female adolescents from the Indian diaspora. Qual Health Res 2009, 19:492-503.

50. Hofman K, Ryce A, Prudhomme W, Kotzin S: Reporting of noncommunicable disease research in low- and middle-income countries: a pilot bibliometric analysis. J Med Libr Assoc 2006, 94:415-420.

51. Mony PK, Srinivasan K: A bibliometric analysis of published noncommunicable disease research in India. Indian J Med Res 2011, 134:232-234.

52. Kumar MS, Sarma PS, Thankappan KR: Community-based group intervention for tobacco cessation in rural Tamil Nadu, India: A cluster randomized trial. J Subst Abuse Treat 2012, 43:53-60.

53. Ramachandran A, Arun N, Shetty AS, Snehalatha C: Efficacy of primary prevention interventions when fasting and post glucose dysglycemia coexist: analysis of the Indian Diabetes Prevention Programmes (IDPP-1 and IDPP-2). Diabetes Care 2010, 33:2164-2168.

54. Mohan V, Shanthirani CS, Deepa M, Datta M, Williams OD, Deepa R: Community empowerment - a successful model for prevention of noncommunicable diseases in India - the Chennai Urban Population Study (CUPS-17). J Assoc Physicians India 2006, 54:858-862.

55. Krishnan A, Ekowati R, Baridalyne N, Kusumawardani N, Suhardi, Kapoor SK, Leowski J: Evaluation of community-based interventions for noncommunicable diseases: experiences from India and Indonesia. Health Promot Int 2011, 26:276-289.

56. Murukutla N, Turk T, Prasad CV, Saradhi R, Kaur J, Gupta S, Mullin S, Ram F, Gupta PC, Wakefield M: Results of a national mass media campaign in India to warn against the dangers of smokeless tobacco consumption. Tob Control 2012, 21:12-17.

57. Painter JE, Borba CP, Hynes M, Mays D, Glanz K: The use of theory in health behavior research from 2000 to 2005: a systematic review. Ann Behav Med 2008, 35:358-362.

58. Sallis JF, Story M, Lou D: Study designs and analytic strategies for environmental and policy research on obesity, physical activity, and diet: recommendations from a meeting of experts. Am J Prev Med 2009, 36(Suppl 2):72-77.

59. Prabhakaran D, Jeemon P, Goenka S, Lakshmy R, Thankappan KR, Ahmed F, Joshi PP, Mohan BV, Meera R, Das MS, Ahuja RC, Saran RK, Chaturvedi V, Reddy KS: Impact of a worksite intervention program on cardiovascular risk factors: a demonstration project in an Indian industrial population. J Am Coll Cardiol 2009, 53:1718-1728.

60. Ministry of Health and Family Welfare, Government of India: Guidelines for Law Enforcers for Effective Implementation of Tobacco Control Laws. Available at: http://www.mpvha.org/tobacco/Initiative.pdf (last accessed 11.02.2013).

61. Sarma I, Sarma PS, Thankappan KR: Awareness attitude and perceived barriers regarding implementation of the cigarettes and other tobacco products act in Assam, India. Indian J Cancer 2010, 47(Suppl):63-68.

62. Ministry of Health \& Family Welfare, Government of India: Operational Guidelines: National Tobacco Control Programme. Available at: http://mohfw. nic.in/WriteReadData/892s/29453109790perational\%20Guidelines.pdf (last accessed 11.02.2013).

63. Press Information Bureau, Government of India: The Impact of NRHM has been felt across States in the form of Improved Healthcare and Greater access to Healthcare. Available at: http://pib.nic.in/newsite/erelease.aspx? relid=34986. (last accessed 10.06.2012).

64. Ministry of Health \& Family Welfare, Government of India: Operational Guidelines: National Programme for Prevention and Control of Cancer, Diabetes, Cardiovascular diseases and Stroke (NPCDCS). Available at: http:// health.bih.nic.in/Docs/Guidelines-NPCDCS.pdf (last accessed 11.02.2013).

65. Raban MZ, Dandona R, Kumar GA, Dandona L: Inequitable coverage of non-communicable diseases and injury interventions in India. Natl Med J India 2010, 23:267-273.

66. Rafalson L, Donahue RP, Dmochowski J, Rejman K, Dorn J, Trevisan M: Cigarette smoking is associated with conversion from normoglycemia to impaired fasting glucose: the western New York health study. Ann Epidemiol 2009, 19:365-371.

67. Eliasson B: Cigarette smoking and diabetes. Prog Cardiovasc Dis 2003, 45:405-413.

68. Fisher EB, Boothroyd Rl, Coufal MM, Baumann LC, Mbanya JC, RotheramBorus MJ, Sanguanprasit B, Tanasugarn C: Peer support for selfmanagement of diabetes improved outcomes in international settings. Health Affairs (Millwood) 2012, 31:130-139.

doi:10.1186/1471-2458-13-95

Cite this article as: Daivadanam M et al: Lifestyle change in Kerala, India: needs assessment and planning for a community-based diabetes prevention trial. BMC Public Health 2013 13:95.

\section{Submit your next manuscript to BioMed Central and take full advantage of:}

- Convenient online submission

- Thorough peer review

- No space constraints or color figure charges

- Immediate publication on acceptance

- Inclusion in PubMed, CAS, Scopus and Google Scholar

- Research which is freely available for redistribution 